\title{
Morphometric differentiation of gudgeon species inhabiting the Carpathian Basin
}

\author{
Péter Takács \\ Balaton Limnological Institute, Centre for Ecological Research of the Hungarian Academy of Sciences (BLI CER HAS), PO Box 35, \\ 8237 Tihany, Hungary
}

Received 9 June 2011; Accepted 16 December 2011

\begin{abstract}
The aim of this study was to examine morphometric differentiation of gudgeon (Romanogobio and Gobio) species inhabiting the Carpathian Basin, Hungary, with special regard to two recently described species classified into the Gobio genus. For statistical analyses, 23 morphometric and 8 meristic characters were measured on each of the 733 preserved specimens originating from museum collections. The analyses of the standardized morphometric traits revealed low intraspecific variability in all studied species, but varying degrees of interspecific differences. The strongest morphometric differentiation was found in Romanogobio uranoscopus (Agassiz, 1828), which can be characterized by the most special environmental needs. The two allopatric Gobio species showed the weakest morphometric difference. The meristic characters showed high variability in the Romanogobio spp., but did not show significant differences in the two Gobio species. The results show that the morphometric and meristic similarity of the studied Gobio species is definitely high, which preclude reliable identification based on phenotypic characters if only some specimens are available. It seems that the most usable discriminating feature for these species is the localization of the collection site.
\end{abstract}

Key words: Gobio obtusirostris / Gobio carpathicus / Romanogobio / meristic and morphometric traits / discriminant analysis

\section{Introduction}

The Gobioninae subfamily forms a distinct taxonomic group within the Cyprinidae family (Kottelat and Freyhof, 2007). This taxon, which consists of about 30 genera and 130 species (Bănărescu, 1992; Bogutskaya and Naseka, 2004; Yang et al., 2006), is widely distributed in Northern Eurasia. Although the highest number of species in the subfamily are present in South-West Asia (Nelson, 2006), a number of gudgeon species also appear in Europe (Kottelat and Freyhof, 2007). Originally all the native European gudgeon species were classified into one genus (Gobio). However, due to clear osteologic differences, a subgenus (Romanogobio) was raised up to genus level (Naseka, 1996; Naseka and Bogutskaya, 1998; Naseka and Poznjak, 2000; Bogutskaya and Naseka, 2004), which yielded the taxonomic revision of many gudgeon species. Nowak et al. (2008a) produced a comprehensive overview of the recent taxonomic status of the European gudgeon species, which can be shortly summarized as follows.

Until the end of the 20th Century, four gudgeon species were known from the Central European Carpathian Basin,

Corresponding author: takacsp@tres.blki.hu which is surrounded by the Carpathian Mountains, the Alps, the Dinarides and the Balkan Mountains. In recent years from the four Carpathian gudgeon species: European gudgeon [Gobio gobio (Linnaeus, 1758)], whitefin gudgeon [Gobio vladykovi (Fang, 1943)], sand gudgeon [Gobio kesslerii (Dybowski, 1862)] and Danube gudgeon [Gobio uranoscopus (Agassiz, 1828)], the latter three were rearranged to the Romanogobio genus. Only the sturdier bodied G. gobio, characterized by its dispersedly spotted dorsal and caudal fins, remained in the genus Gobio. The distribution area of this species covers almost the whole of Europe, and it can be found in highly different habitats (lentic and lotic). Consequently, considerable morphometric differences were found among its populations and many subspecies were described (Bănărescu, 1999). The G. gobio was considered as a common species in the Carpathian Basin as well (Harka and Sallai, 2004) and regarded as an indicator fish species of submontane/ highland streams in their "natural" state (Erös, 2007; Takács, 2007; Sály et al., 2009).

Some authors (e.g., Vladykov, 1925; Jászfalusi, 1951; Bănărescu, 1954; Berinkey, 1962) noticed notable morphological differentiation of G. gobio stocks inhabiting the Tisza drainage system, located at the eastern part of the 
Carpathian Basin. The differences, however, were not considered to provide species level differentiation between the gudgeon stocks found in the eastern and the western part of the Carpathian Basin.

Molecular methods have also resulted in considerable taxonomic changes in the gudgeons of Central Europe. Based on genetic investigations (Freyhof and Naseka, 2005; Mendel et al., 2008), the species G. gobio extends widely from the British Isles to the Black Sea coast. However, contrary to the former suppositions, this species is not indigenous in waters of the Carpathian Basin. As a result of this, a recent identification key (Kottelat and Freyhof, 2007), does not mention that the G. gobio is from this area. Conversely, two other gudgeon species, the Carpathian gudgeon (Gobio carpathicus Vladykov, 1925) and the Danube gudgeon (Gobio obtusirostris Cuvier and Valenciennes, 1842) are denoted from the Carpathain Basin. Both species are mentioned as synonyms of G. gobio by Bănărescu (1999). The border between the distribution areas of these species is formed by the North-South flow of the Hungarian Danube section (Kottelat and Freyhof, 2007). The G. carpathicus, originally described as G. gobio carpathicus by Vladykov (1925), is distributed in the drainage system of River Tisza, the largest tributary of the Danube (catchment area: $157000 \mathrm{~km}^{2}$ ). Berinkey (1962) agrees with Bănărescu's (1954) opinion that the drainage system of the Upper and Middle Tisza is "terra typica" of this subspecies. Moreover, Jászfalusi (1951) described another subspecies from this drainage, named G. gobio muresia. Its distribution area is limited to one of the tributaries of the Lower Tisza drainage system. This subspecies complies with the G. carpathicus by Kottelat and Freyhof (2007).

The Danube gudgeon was originally described from a tributary of the Upper Danube. It is indigenous in the inflows of the Upper and Middle Danube, thus should be common in the drainage system of the Transdanubian region in Hungary (Kottelat and Freyhof, 2007). Although the genetic investigations show species level differentiations of the Gobio species inhabiting the Eastern and Western regions of the Carpathian Basin, their morphological differences have not been examined in detail so far. Further, the morphological keys given by Kottelat and Freyhof (2007) cannot be really used for distinguishing species inhabiting the Carpathian Basin, because they show complete overlap between the G. carpathicus and G. obtusirostris. Hungarian museum collections contain many gudgeon specimens that originate from numerous localities throughout the Carpathian Basin (e.g., Sevcsik and Erôs, 2008), with a high number of specimens originally identified as G. gobio. If it is accepted that G. gobio cannot be found in the Carpathian Basin, but there are two other Gobio species native in this area, then all the specimens previously identified as G. gobio must be assigned into these taxa. According to the map and area descriptions provided by Kottelat and Freyhof (2007), all the Gobio specimens originating from the western area of the Carpathian Basin (Transdanubian region) should be identified as G. obtusirostris, while all the Gobio specimens

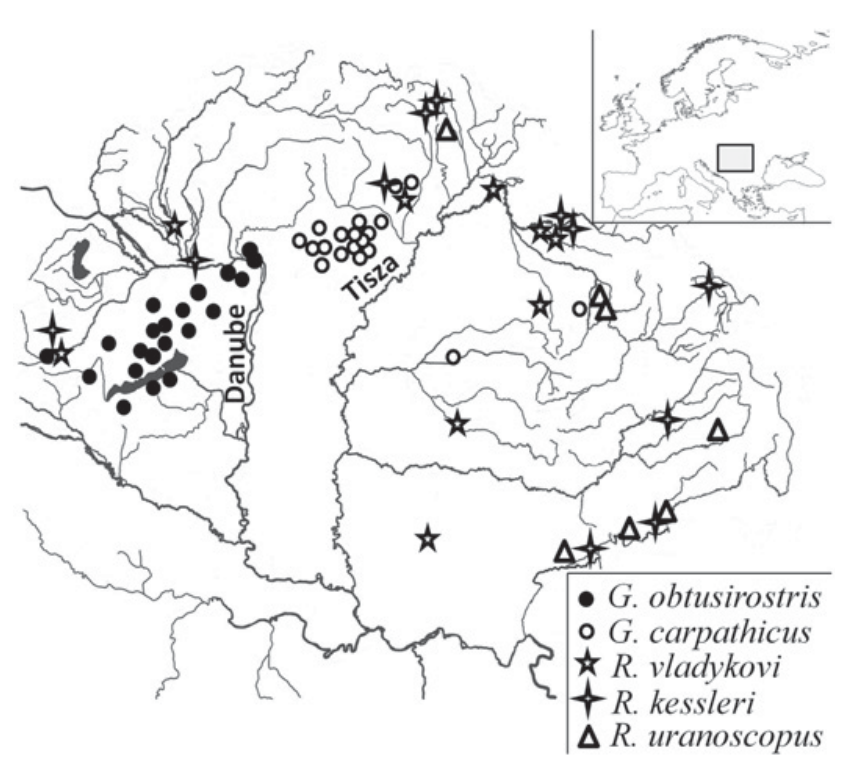

Fig. 1. European localization of the Carpathian Basin (a) and the collection sites in the basin (b).

collected from the Upper- and Middle-Tisza drainage should be identical to G. carpathicus. Consequently, to identify the scale of interspecific differentiations, hundreds of preserved specimens are available in museum collections. Consequently, the aim of this study is to identify the extent of morphometric differences between the gudgeon species inhabiting the Carpathian Basin, having special regard to the species classified into the Gobio genus using preserved specimens in museum collections.

\section{Materials and methods}

Specimens used for the morphometric studies originated from three Hungarian museums (Hungarian Natural History Museum, Budapest; Bakony Museum, Zirc; and Mátra Museum, Gyöngyös). Altogether 733 gudgeon specimens were measured. The number of preserved specimens of each species correlated well with their occurrence in Hungarian waters (personal observation). The highest number of specimens was species previously identified as $G$. gobio $(n=409)$. From the Upper- and Middle-Tisza drainage system, 202 G. carpathicus specimens from 19 localities were measured and from the Western part of the basin, 207 G. obtusirostris specimens from 21 localities were measured. From the Romanogobio genus, specimens of $128 R$. vladykovi from 9 localities, 135 R. kesslerii from 11 localities and $61 R$. uranoscopus from 7 localities were used in the analyses (Fig. 1). Altogether 23 morphometric characters (Fig. 2) were measured on each specimen with a digital calliper, which were found to be the most important variables in the morphometric identification of gobionins (Bănărescu, 1954, 1999; Berinkey, 1966; Harka, 1986). Standard length (SL) was measured to the end of scale cover.

Preservation causes deformations on the body shape (Shields and Carlson, 1996; Neave et al. 2006), but it was 


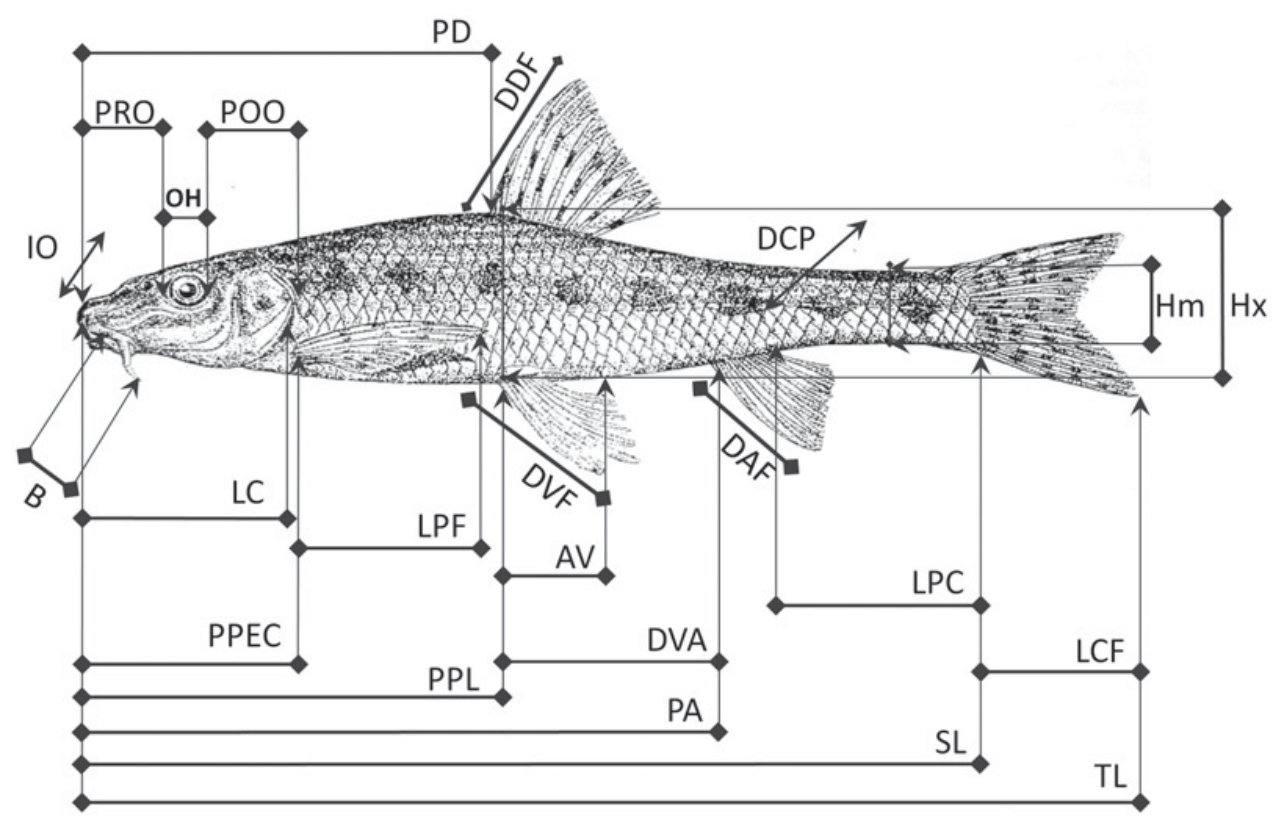

Fig. 2. Morphometric characters measured. Abbreviations: AV, distance between the anal aperture and ventral fin; B, length of barbel; DAF, depth of anal fin; DCP, diameter of caudal peduncle; DDF, depth of dorsal fin; DVA, distance between the ventral and anal fin; DVF, depth of ventral fin; Hx, maximum body depth; IO, interorbital distance; LC, head length; LCF, length of caudal fin; LPC, length of caudal peduncle; LPF, length of pectoral fin; Mm, minimum body depth; OH, eye diameter; PA, preanal distance; PD, predorsal distance; POO, postorbital distance; PPEC, prepectoral distance; PPL, prepelvic distance; PRO, preorbital distance; SL, standard length; TL, total length.

assumed that these deformations affected each specimen uniformly. To minimize conservation bias and ontogenic differences, only the well preserved, adult (SL > $50 \mathrm{~mm}$ ) specimens were used for our study (Bănărescu, 1999). In order to eliminate any size effect in the dataset, the allometric formula of Elliott et al. (1995) was used:

$$
M_{\text {adj }}=M\left(L_{\mathrm{s}} / L_{\mathrm{o}}\right)^{b}
$$

where is the original measurement, $M_{\mathrm{adj}}$ is the size adjusted measurement, $L_{\mathrm{o}}$ is the SL of fish, $L_{\mathrm{s}}$ is the overall mean of SL for all fish from all samples in each analysis.

Parameter " $b$ " was estimated for each character from the observed data as the slope of the regression of $\log M$ on $\log L_{\mathrm{o}}$, using all fish in all groups. The efficiency of size adjustment transformations was assessed by testing the significance of correlations between transformed variables and SL.

To determine the scale of the intraspecific variability, all the standardized data of each specimen were compared with the others classified into the same species using the Bray-Curtis similarity index. Uni- and multivariate analysis of variance (ANOVA) were carried out to test the significance of morphometric differences among the studied species. On the entire standardized dataset principal component analysis (PCA) and discriminant analyses were performed. To test the among species similarities, analysis of similarity (ANOSIM) was used. The between species differences were analysed by ANOVA, Tukey post hoc test for each variable. Statistical analyses were performed using SPSS v12.0.1 and PAST 1.95 (Hammer et al., 2001), graphs were generated using PAST 1.95 and Syn-Tax 2000 (Podani, 2001).

Altogether eight meristic variables were studied. The investigated meristic variables were the number of scales on the lateral line, the number of scales above and below the lateral line, and the number of soft fin rays. The variances of the meristic data were compared using Kruskal-Wallis tests.

\section{Results}

For each species, the ranges (min-max) and the means $( \pm \mathrm{SD})$ of SL, and the values of the other characters as a percentage of SL and head length (LC) are shown in Table 1. After the allometric transformation, only total length (TL) showed significant correlation $(P<0.05)$ with the SL. This result indicates that the size effect was removed effectively in the case of the other 21 characters studied.

Considering the entire dataset, the mean intraspecific similarity proved to be high in all cases ( $R$. uranoscopus: $0.966 \pm 0.01, \quad R$. kesslerii: $0.965 \pm 0.01, R$. vladykovi: $0.962 \pm 0.01, \quad$ G. obtusirostris: $0.962 \pm 0.01$, G. carpathicus: $0.960 \pm 0.01)$. The univariate ANOVA revealed significant differences between the means of the five gudgeon species for all the 21 standardized morphometric variables $(P<0.01)$. The comparison of the within and among group variations ( $F$-ratios) referred to the maximum $(\mathrm{Hx})$ and minimum $(\mathrm{Hm})$ body height, the post (POO) and interorbital distances (IO) and LC are the most 
Table 1. Morphometric characteristic of the analysed gudgeons. The meaning of the abbreviations can be found in the caption of Figure 2.

\begin{tabular}{|c|c|c|c|c|c|}
\hline & Go & Gc & $\mathrm{Rv}$ & $\mathrm{Rk}$ & $\mathrm{Ru}$ \\
\hline$\overline{\mathrm{SL}}(\min -\max )$ & $53.4-110.8$ & $51.9-111.8$ & $52.7-99.7$ & $51.8-100.2$ & $50.7-99.8$ \\
\hline $\mathrm{SL}($ mean $\pm \mathrm{SD})$ & $75.91 \pm 15.1$ & $76.26 \pm 14.4$ & $74.30 \pm 17.4$ & $84.16 \pm 17.3$ & $83.37 \pm 14.4$ \\
\hline \multicolumn{6}{|l|}{ Percentage of SL } \\
\hline $\mathrm{AV}$ & $0.11 \pm 0.03$ & $0.11 \pm 0.02$ & $0.13 \pm 0.05$ & $0.11 \pm 0.04$ & $0.09 \pm 0.02$ \\
\hline DAF & $0.19 \pm 0.04$ & $0.18 \pm 0.04$ & $0.21 \pm 0.06$ & $0.19 \pm 0.04$ & $0.22 \pm 0.04$ \\
\hline DCP & $0.06 \pm 0.02$ & $0.05 \pm 0.01$ & $0.07 \pm 0.02$ & $0.06 \pm 0.01$ & $0.07 \pm 0.02$ \\
\hline DDF & $0.18 \pm 0.04$ & $0.17 \pm 0.03$ & $0.20 \pm 0.05$ & $0.18 \pm 0.04$ & $0.21 \pm 0.04$ \\
\hline DVA & $0.19 \pm 0.04$ & $0.19 \pm 0.04$ & $0.24 \pm 0.07$ & $0.20 \pm 0.05$ & $0.19 \pm 0.04$ \\
\hline DVF & $0.18 \pm 0.04$ & $0.17 \pm 0.03$ & $0.20 \pm 0.05$ & $0.18 \pm 0.04$ & $0.21 \pm 0.04$ \\
\hline $\mathrm{Hm}$ & $0.11 \pm 0.02$ & $0.10 \pm 0.02$ & $0.11 \pm 0.04$ & $0.08 \pm 0.02$ & $0.08 \pm 0.02$ \\
\hline $\mathrm{Hx}$ & $0.24 \pm 0.06$ & $0.22 \pm 0.04$ & $0.26 \pm 0.08$ & $0.19 \pm 0.05$ & $0.20 \pm 0.04$ \\
\hline $\mathrm{LC}$ & $0.29 \pm 0.06$ & $0.28 \pm 0.06$ & $0.31 \pm 0.09$ & $0.27 \pm 0.06$ & $0.30 \pm 0.06$ \\
\hline $\mathrm{LCF}$ & $0.21 \pm 0.05$ & $0.20 \pm 0.05$ & $0.26 \pm 0.07$ & $0.22 \pm 0.05$ & $0.23 \pm 0.05$ \\
\hline LPC & $0.24 \pm 0.05$ & $0.24 \pm 0.05$ & $0.29 \pm 0.08$ & $0.27 \pm 0.06$ & $0.28 \pm 0.05$ \\
\hline LPF & $0.22 \pm 0.05$ & $0.21 \pm 0.05$ & $0.25 \pm 0.06$ & $0.23 \pm 0.05$ & $0.27 \pm 0.06$ \\
\hline PA & $0.75 \pm 0.16$ & $0.75 \pm 0.15$ & $0.90 \pm 0.27$ & $0.75 \pm 0.16$ & $0.78 \pm 0.15$ \\
\hline PD & $0.51 \pm 0.11$ & $0.51 \pm 0.10$ & $0.59 \pm 0.17$ & $0.51 \pm 0.11$ & $0.56 \pm 0.10$ \\
\hline PPEC & $0.28 \pm 0.06$ & $0.27 \pm 0.06$ & $0.31 \pm 0.10$ & $0.26 \pm 0.06$ & $0.28 \pm 0.06$ \\
\hline PPL & $0.52 \pm 0.11$ & $0.52 \pm 0.11$ & $0.61 \pm 0.18$ & $0.52 \pm 0.11$ & $0.56 \pm 0.11$ \\
\hline \multicolumn{6}{|l|}{ Percentage of LC } \\
\hline $\mathrm{B}$ & $0.29 \pm 0.05$ & $0.25 \pm 0.04$ & $0.33 \pm 0.06$ & $0.34 \pm 0.05$ & $0.38 \pm 0.06$ \\
\hline $\mathrm{IO}$ & $0.26 \pm 0.02$ & $0.26 \pm 0.02$ & $0.26 \pm 0.02$ & $0.24 \pm 0.02$ & $0.24 \pm 0.02$ \\
\hline $\mathrm{OH}$ & $0.23 \pm 0.02$ & $0.23 \pm 0.02$ & $0.26 \pm 0.03$ & $0.23 \pm 0.02$ & $0.20 \pm 0.02$ \\
\hline $\mathrm{POO}$ & $0.44 \pm 0.03$ & $0.45 \pm 0.03$ & $0.41 \pm 0.03$ & $0.42 \pm 0.03$ & $0.40 \pm 0.02$ \\
\hline PRO & $0.37 \pm 0.03$ & $0.35 \pm 0.04$ & $0.36 \pm 0.03$ & $0.38 \pm 0.03$ & $0.44 \pm 0.03$ \\
\hline
\end{tabular}

Table 2. $F$-ratios and among species comparisons of the studied variables.

\begin{tabular}{|c|c|c|c|c|c|c|c|c|c|c|}
\hline & $F$-ratio & Gc & dif & Go & dif & $\mathrm{Rv}$ & dif & Rk & dif & $\mathrm{Ru}$ \\
\hline$\overline{\mathrm{Hm}}$ & 464.8 & $\mathrm{~A}$ & $=$ & $\mathrm{A}$ & $>$ & B & $>$ & $\mathrm{C}$ & $=$ & $\overline{\mathrm{C}}$ \\
\hline $\mathrm{Hx}$ & 278.2 & A & $=$ & A & $>$ & B & $>$ & C & $=$ & C \\
\hline POO & 173.6 & A & $=$ & A & $>$ & B & $=$ & B & $=$ & B \\
\hline IO & 117.9 & A & $=$ & A & $>$ & B & $>$ & $\mathrm{C}$ & $<$ & B \\
\hline LC & 114.6 & A & $>$ & B & $>$ & C & $=$ & C & $<$ & D \\
\hline B & 98.2 & A & $>$ & B & $<$ & $\mathrm{AC}$ & $=$ & C & $<$ & D \\
\hline $\mathrm{OH}$ & 94.2 & A & $=$ & A & $<$ & B & $>$ & C & $>$ & D \\
\hline PRO & 91.9 & A & $>$ & B & $>$ & C & $<$ & B & $<$ & D \\
\hline PPEC & 77.4 & A & $=$ & A & $>$ & B & $>$ & C & $<$ & D \\
\hline LPF & 69.7 & A & $>$ & B & $=$ & B & $<$ & A & $<$ & $\mathrm{C}$ \\
\hline PD & 54.6 & A & $=$ & A & $>$ & B & $=$ & B & $<$ & A \\
\hline DAF & 53.8 & A & $>$ & B & $=$ & B & $=$ & B & $<$ & C \\
\hline DVF & 44.5 & A & $>$ & B & $=$ & B & $=$ & B & $<$ & $\mathrm{C}$ \\
\hline DCP & 39.0 & A & $>$ & B & $<$ & A & $=$ & A & $<$ & $\mathrm{C}$ \\
\hline LPC & 38.2 & $\mathrm{AB}$ & $=$ & A & $>$ & B & $>$ & C & $=$ & C \\
\hline PA & 35.9 & A & $=$ & A & $=$ & A & $>$ & B & $=$ & B \\
\hline AV & 34.8 & A & $=$ & A & $=$ & A & $>$ & B & $>$ & $\mathrm{C}$ \\
\hline PPL & 30.9 & A & $=$ & A & $>$ & B & $>$ & C & $<$ & D \\
\hline DDF & 19.3 & A & $>$ & B & $<$ & A & $>$ & C & $=$ & C \\
\hline DVA & 17.8 & A & $=$ & $\mathrm{AB}$ & $=$ & B & $=$ & $\mathrm{AB}$ & $>$ & $\mathrm{C}$ \\
\hline LCF & 5.7 & A & $=$ & A & $<$ & B & $=$ & $\mathrm{AB}$ & $=$ & $\mathrm{AB}$ \\
\hline
\end{tabular}

Variables marked by the same letters do not differ significantly $(P>0.05)$ based on ANOVA post hoc comparisons. Abbreviations: dif, difference; Gc, G. carpathicus stock from the eastern area of the Carpathian Basin; Go, G. obtusirostris stock from the western area of the Carpathian Basin; Rv, R. vladykovi; Rk, R. kesslerii; Ru, R. uranoscopus. The meaning of the abbreviations can be found in the caption of Figure 2.

important variables measured, those were responsible for the global (interspecific) differentiations (Tab. 2). The ANOVA Tukey post hoc test (Tab. 2) showed significant between species differences for each variable. The highest similarity was found between the two Gobio species, from the studied 21 characters only 8 showed significant differences. The results of PCA showed considerable differentiations in the case of $R$. uranoscopus and $R$. kesslerii 


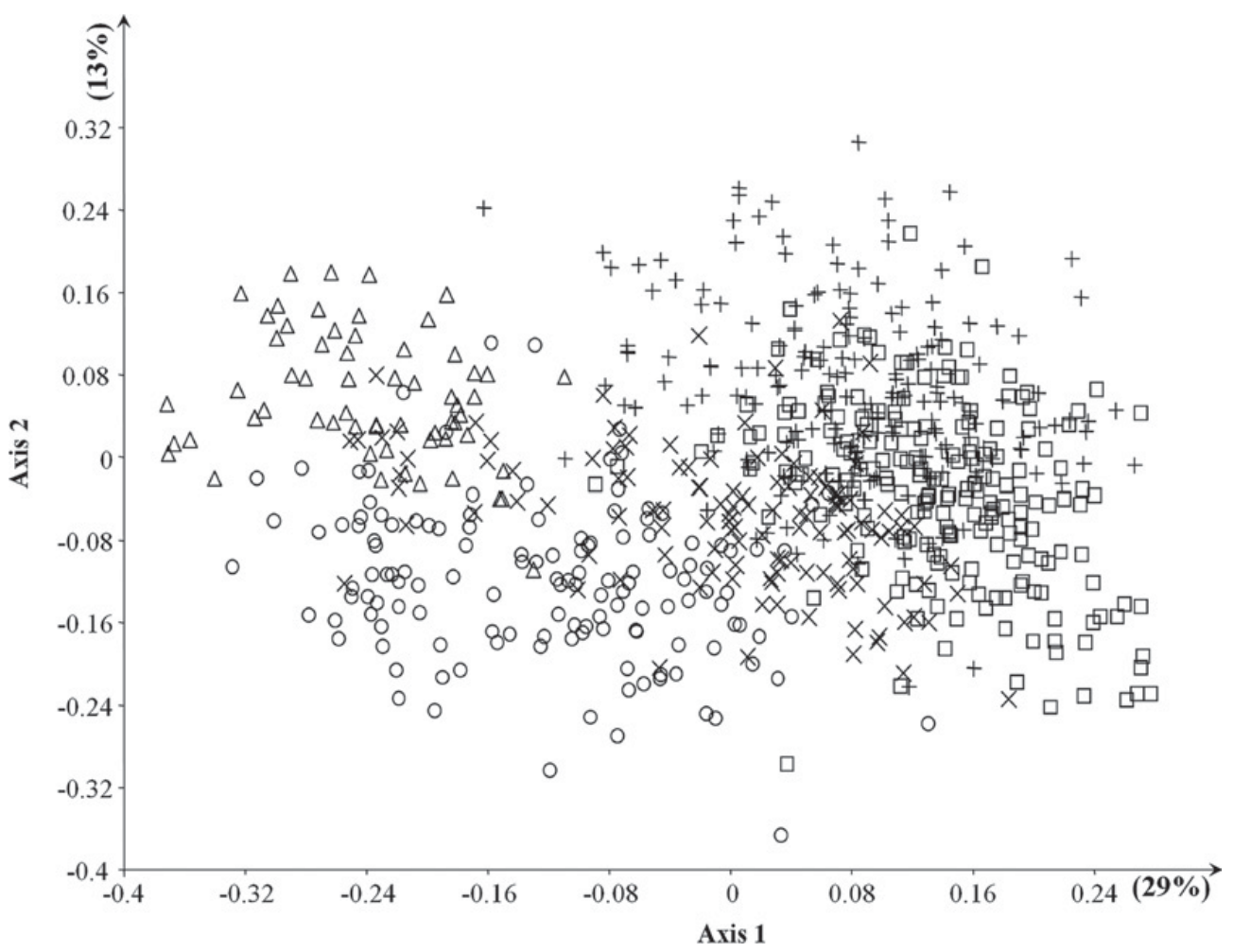

Fig. 3. PCA plot of morphometric data. $\triangle$, R. uranoscopus; $\bigcirc$, R. kesslerii; X, R. vladykovi; +, G. carpathicus stock from the eastern area of the Carpathian Basin; $\square$, G. obtusirostris stock from the western area of the Carpathian Basin.

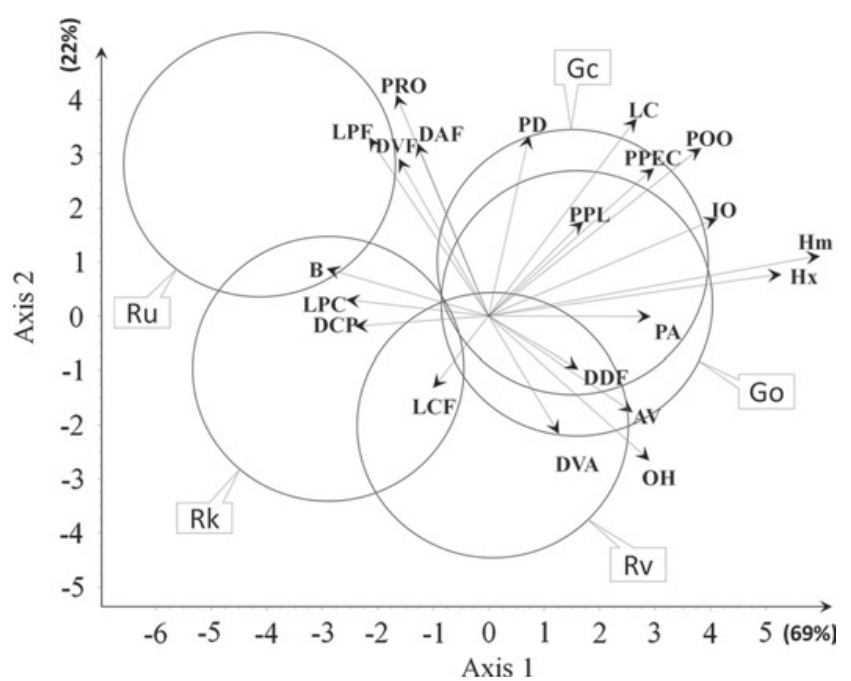

Fig. 4. Plot of the discriminant analysis derived from morphometric data. Abbreviations: Gc: G. carpathicus stock from the eastern area of the Carpathian Basin; Go, $G$. obtusirostris stock from the western area of the Carpathian Basin; Rv, R. vladykovi; Rk, R. kesslerii; Ru, R. uranoscopus. The isodenity circles contain the $95 \%$ of the specimens classified into a certain group. The meaning of the abbreviations can be found in the caption of Figure 2.

stocks than the others (Fig. 3). The statistical analysis of the entire dataset using ANOSIM showed that all the studied groups differ significantly $(P<0.01)$ from the others.
The discriminant analysis showed remarkable differences between the studied Romanogobio species (Fig. 4). Data points belonging to the two Gobio species showed almost complete overlap, which is also indicated by the isodensity circles, which contain $95 \%$ of the specimens classified into a certain group (Fig. 4). The overall random assignment of individuals into their original group was $84.7 \%$ (Tab. 3). The proportion of individuals correctly classified into their original group was highest in the case of $R$. kesslerii $(97.3 \%)$ and $R$. uranoscopus $(95.1 \%)$, indicating that these samples are highly different from the others. In the case of $R$. vladykovi, the proportion was lower $(86.7 \%)$. The two Gobio species had the highest proportion of misclassified cases, with their original (preliminary) classification proving the most doubtful (73.3 and $83.6 \%$ for G. carpathicus and the G. obtusirostris, respectively). From the misclassified specimens in these groups 24.3 and $14 \%$ were classified into the group of the other Gobio species. The study made on the eight meristic variables (Tab. 4) showed significant differences between the Romanogobio species (e.g., the number of scales above the lateral line and the number of soft rays), but no significant differences were found between the two Gobio species in any cases.

\section{Discussion}

Morphometric and meristic traits have been used for a long time for the identification of European gudgeon 
Table 3. Comparison of the original and the predicted group memberships given by the discriminant analysis.

\begin{tabular}{|c|c|c|c|c|c|c|c|}
\hline \multirow[b]{2}{*}{ Original grouping } & & & \multicolumn{5}{|c|}{ Predicted group memberships } \\
\hline & & & $\mathrm{Gc}$ & Go & $\mathrm{Rv}$ & Rk & $\mathrm{Ru}$ \\
\hline \multirow[t]{5}{*}{ Specimen number } & $\mathrm{Gc}$ & 202 & 148 & 49 & 5 & 0 & 0 \\
\hline & Go & 207 & 29 & 173 & 5 & 0 & 0 \\
\hline & $\mathrm{Rv}$ & 128 & 5 & 7 & 111 & 5 & 0 \\
\hline & Rk & 135 & 0 & 0 & 4 & 131 & 0 \\
\hline & $\mathrm{Ru}$ & 61 & 0 & 0 & 0 & 3 & 58 \\
\hline \multirow[t]{5}{*}{ Percent $(\%)$} & Gc & 100 & 73.3 & 24.3 & 2.5 & 0.0 & 0.0 \\
\hline & Go & 100 & 14.0 & 83.6 & 2.4 & 0.0 & 0.0 \\
\hline & $\mathrm{Rv}$ & 100 & 3.9 & 5.5 & 86.7 & 3.9 & 0.0 \\
\hline & $\mathrm{Rk}$ & 100 & 0.0 & 0.0 & 3.0 & 97.0 & 0.0 \\
\hline & $\mathrm{Ru}$ & 100 & 0.0 & 0.0 & 0.0 & 4.9 & 95.1 \\
\hline
\end{tabular}

Gc, G. carpathicus stock from the eastern area of the Carpathian Basin; Go, G. obtusirostris stock from the western area of the Carpathian Basin; Rv, R. vladykovi; Rk, R. kesslerii; Ru, R. uranoscopus.

Table 4. The average (min-max) values of meristic variables counted on gudgeon specimens.

\begin{tabular}{|c|c|c|c|c|c|c|c|c|c|c|}
\hline \multicolumn{2}{|c|}{$\overline{\text { Meristic variables }\left(\mathrm{N}^{\circ}\right)}$} & $\mathrm{Gc}$ & $P$ & Go & $P$ & $\mathrm{Rv}$ & $P$ & $\mathrm{Rk}$ & $P$ & $\mathrm{Ru}$ \\
\hline \multirow[t]{3}{*}{$\begin{array}{l}\text { Scales } \\
\text { scis }\end{array}$} & On the lateral line & $40.4(39-43)$ & ns & $40.0(38-42)$ & $\bullet$ & $42.6(40-44)$ & ns & $42.8(40-44)$ & ns & $\overline{42.0(40-43)}$ \\
\hline & Above the lateral line & $5.3(5-6)$ & ns & $5.1(5-6)$ & ns & $4.9(4-5)$ & $\bullet$ & $4.4(4-5)$ & $\bullet$ & $5.0(5-5)$ \\
\hline & Below the lateral line & $3.6(3-4)$ & ns & $3.6(3-4)$ & $\bullet$ & $3.1(3-4)$ & ns & $3.0(3-4)$ & ns & $3.0(3-3)$ \\
\hline \multirow[t]{5}{*}{ Soft rays in } & Pectoral fin & $12.6(12-13)$ & ns & $12.2(12-13)$ & $\bullet$ & $11.7(11-13)$ & $\bullet$ & $13.4(12-14)$ & ns & $13.0(13-13)$ \\
\hline & Ventral fin & $6.6(6-7)$ & ns & $6.3(6-7)$ & ns & $6.7(6-7)$ & ns & $6.8(6-8)$ & $\bullet$ & $6.1(6-7)$ \\
\hline & Anal & $5.9(5-7)$ & ns & $5.8(5-7)$ & ns & $6.0(6-6)$ & ns & $6.7(6-7)$ & ns & $6.3(6-7)$ \\
\hline & Dor: & $7.0(7-7)$ & ns & $7.0(7-7)$ & ns & $7.0(7-7)$ & $\bullet$ & $8.0(8-8)$ & $\bullet$ & $7.0(7-7)$ \\
\hline & Caudal fin & $19.4(18-20)$ & ns & $19.5(18-21)$ & ns & $19.3(19-20)$ & • & $18.6(18-20)$ & ns & $19.0(19-19)$ \\
\hline
\end{tabular}

$\bullet=P<0.05, \mathrm{~ns}=P>0.05 ; \mathrm{Gc}$, G. carpathicus stock from the eastern area of the Carpathian Basin; Go, G. obtusirostris stock from the western area of the Carpathian Basin; Rv, R. vladykovi; Rk, R. kesslerii; Ru, R. uranoscopus.

species (Berg, 1949; Bănărescu, 1954, 1961, 1962, 1999; Vasil'eva et al., 2004, 2005; Kottelat and Persat, 2005; Naseka et al., 2006; Kottelat and Freyhof, 2007; Nowak et al., 2008b, 2009, 2011). But whereas the ranges of the morphometric variables usually overlap, the application of these traits for taxa differentiation is questioned by many authors (e.g., Bănărescu, 1961, 1962, 1999; Koščo, 1997; Mendel et al., 2008). The present study revealed varying degrees of morphometric and meristic differences in the gudgeon species inhabiting the Carpathian Basin. The results show that all these gudgeon species are distinguishable if a proper number of morphometric characters are used. By completing detailed measurements, significant differences in body shape and the meristic characters can be found among the Romanogobio species inhabiting the area. The discriminating traits among these three species agree well with data in the literature (Bănărescu, 1999; Kottelat and Freyhof, 2007).

The morphologic differences show high similarity with the habitat preferences of the studied species. The highest interspecific and the lowest intraspecific variation were found in $R$. uranoscopus. This species can be characterized by the most different body shape, caused by its adaption to the environmental circumstances of mountain rivers (e.g., the deepest fusiform body shape, the longest paired fins and the most elongated caudal peduncle, etc.). The other two Romanogobio species appear commonly in the same habitats in the upper sections of the Hungarian lowland rivers (Harka and Sallai, 2004). The morphometric traits of the $R$. kesslerii show transition between the $R$. uranoscopus and the $R$. vladykovi (Fig. 3). Notwithstanding they can be separated from good efficiency using the combination of the morphometric characters measured.

At the same time, remarkable differences were also found in the case of meristic characters, especially for the number of soft rays in the dorsal fins. Among the Romanogobio species only the $R$. vladykovi shows major overlap with the Gobio species morphologically. Simultaneously, this is the only Romanogobio species that commonly appears in the preferred habitat types of the Gobio species (Bănărescu, 1964; Harka et al., 2004). The high-level morphologic similarity in the case of the species inhabiting the same habitat types, may suggest that the same kind of adaptation to the environmental circumstances occurred. But it is more likely that interspecific hybridization can occur between these closely related species. And these hybrids may show transitional morphologic traits, or the descendants show both parents' traits at the same time. According to some authors the intraspecific hybridization is plausible in the case of Central European gudgeon species (Bănărescu, 1999; Mendel et al., 2008). The presence of hybrids in the museum collections cannot be ruled out as well. The detection of some hybrid specimens is plausible taking into account the body shape and the presence or absence of the epidermal crests on the dorsal region. But, I think, the identification of the F2, F3, etc. generation hybrids are impossible using just only morphometric methods. 
For proving the effect of hybridization on the body shape simultaneous genetic and morphometric measurements would be needed. Unfortunately, the specimens studied were mostly preserved in formalin, thus genetic studies were unaccomplishable in this case.

The highest level of morphometric similarity was detected between the two Gobio species. This, however, was not a consequence of hybridization, as there are considerable hydrological distances between their occurrences. In the case of small bodied, benthic fish species that are characterized by shorter generation time, the effect of genetic drift is much more significant than in the case of other species (e.g., migratory species) characterized by other life strategies (Hänfling and Brandl, 1998a, b; Brito and Coelho, 1999). Moreover, the Carpathian Basin was not glaciated during the ice age (Taberlet et al., 1998; Emerson and Hewitt, 2005) so the separation and the restricted gene flow between the eastern and western Gobio populations may have existed for a long time. This may cause significant differences in phenotypic traits. In addition, a previous study conducted in the Middle-Tisza drainage showed remarkable genetic differences between the Gobio populations within small spatial scales as well (Takács et al., 2008).

Notwithstanding the high Gobio specimen number (the comparison of more than 8500 data of 409 specimens), the morphometric differences found less pronounced than in the case of the three Romanogobio species. Only 8 of the 21 morphometric traits used for the analysis showed significant differences. It should be noted that more than twice as many specimens were measured in the case of the two Gobio species, as in the case of the other three, and these Gobio specimens may have originated from collection sites characterized with highly different environmental conditions. As it is proved in many cases (Karakousis et al., 1991; Bourke et al., 1997; Fulton et al., 2001; Brinsmead and Fox, 2002; Turan et al., 2005; Çakmak and Alp, 2010), environmental circumstances can significantly affect the morphologic features. It may be presumed that stocks originating from higher numbers of collection sites show higher morphologic variability. In our case the intraspecific similarities were exactly the same, above $95 \%$ in the case of each species. Therefore, the higher specimen number and the higher number of collection sites in the case of Gobio species did not affect our results considerably.

Within field conditions, the countable, meristic traits are much more usable for identification than the morphometric features, which need standardization. Results show convincingly that the combination of these traits is well applicable for differentiating the Romanogobio species. But in the case of G. obtusirostris and G. carpathicus the meristic traits used did not show significant detachments, thus these characters are not usable for differentiation.

In summary, considerably higher differences were encountered among the Romanogobio species inhabiting the Carpathian Basin than in the case of the two newly described Gobio species native in this area. Although the detailed morphometric studies showed significant differentiation among all the studied species, these results are assignable to the high specimen number. As the extent of similarity between the studied Gobio species is high and the meristic traits show no significant differences then their differentiation is difficult if there are only a small number of specimens available. Moreover, it seems that the most usable discriminating feature for these species is the localization of the collection site. Regarding the fact that a genetic study (Mendel et al., 2008) classified these two species into different lineages, it is suggested that these taxa can be handled as sibling species (Bickford et al., 2007). Although molecular biology studies have proved genetic isolation, the segregation has not been apparent morphometrically.

Acknowledgements. I thank the Hungarian Natural History Museum, the Bakony Museum and the Mátra Museum for giving the opportunity to take measurements of their fish collections. The study was supported by the OTKA CNK 80140 research fund.

\section{References}

Bănărescu P., 1961. Weitere systematische studien über die Gattug Gobio (Pisces, Cyprinidae) insbesondere im Donaubecken. Vestn. Česko-Slov. Zool. Spol., 25, 318-346.

Bănărescu P.M., 1954. Biometrische und systematische studien an Gobio gobio aus Rumänien. Věstn. Čsl. Zool. Spol., 18, 6-40.

Bănărescu P.M., 1962. Phylletische Beziehungen der Arten und Artbildung bei der Gattung Gobio (Pisces, Cyprinidae). Vest. Cs. Zool. Spol., 26, 38-64.

Bănărescu P.M., 1964. Pisces - Osteichthyes (pesti ganoizi si osisi), Fauna Rep. Pop. Romîne, Vol. 13, Ed. Acad. Rep. Pop. Romîne, Bucurest, 959 p.

Bănărescu P.M., 1992. A critical updated checklist of Gobioninae (Pisces, Cyprinidae). Trav. Mus. Hist. Nat. "Grigore Antipa", 32, 303-330.

Bănărescu, P.M., 1999. Cyprinidae 2/I. In: Bănărescu P.M. (ed.), The Freshwater Fishes of Europe, Vol. 5/I, Aula-Verlag Gmbh., Wiebelsbeim, 134-136.

Berg L.S., 1949. Fishes of fresh waters of the USSR and adjacent countries. Izd. Akad. Nauk SSSR, 2, 469-925.

Berinkey L., 1962. On the taxonomic place of the Hungarian populations of Gobio gobio L. (Pisces, Cyprinidae). Ann. Hist.-Nat. Mus. Nat. Hung., 54, 483-494.

Berinkey L., 1966. Halak-Pisces, Fauna Hungarie, Akadémiai Kiadó, Budapest, 132 p.

Bickford D., Lohman D.J., Navjot S.S., Ng P.K.L., Meier R., Winker K., Ingram K.K. and Das I., 2007. Cryptic species as a window on diversity and conservation. Trends Ecol. Evol., $22,148-155$.

Bogutskaya N.G. and Naseka A.M., 2004. Catalogue of agnathans and fishes of fresh and brackish waters of Russia with comments on nomenclature and taxonomy, KMK Scientific Press Ltd, Moscow, 389 p.

Bourke P., Magnan P. and Rodriquez M.A., 1997. Individual variations in habitat use and morphology in brook charr. J. Fish Biol., 51, 783-794. 
Brinsmead J. and Fox M.G., 2002. Morphological variation between lake- and stream-dwelling rock bass and pumpkinseed populations. J. Fish Biol., 61, 1619-1638.

Brito R.M. and Coelho M.M., 1999. Genetic structure of the Iberian chub, Leuciscus pyrenaicus, in the Tejo drainage. Hydrobiologia, 392, 169-177.

Çakmak E. and Alp A., 2010. Morphological differences among the mesopotamian spiny eel, Mastacembelus mastacembelus (Banks \& Solander 1794) populations. Turk. J. Fish. Aquat. Sci., 10, 87-92.

Cuvier G. and Valenciennes A., 1842. Historie Naturelle des Poissons, P. Bertrand ed., Paris, 16: 474 p., pl. 456-487. II.

Elliott N.G., Haskard K. and Koslow J.A., 1995. Morphometric analysis of orange roughy (Hoplostethus atlanticus) off the continental slope of southern Australia. J. Fish Biol., 46, 202-220.

Emerson B.C. and Hewitt G.M., 2005. Phylogeography. Curr. Biol., 15, R367-R371.

Erős T., 2007. Partitioning the diversity of riverine fish: the roles of habitat types and non-native species. Freshw. Biol., 52, $1400-1415$.

Freyhof J. and Naseka A.M., 2005. Gobio delyamurei, a new gudgeon from Crimea, Ukraine (Teleostei: Cyprinidae). Ichthyol. Explor. Freshw., 16, 331-338.

Fulton C.J., Bellwood D.R. and Wainwright P.C., 2001. The relationship between swimming ability and habitat use in wrasses (Labridae). Mar. Biol., 139, 25-33.

Hammer Ø., Harper D.A.T. and Ryan P.D., 2001. PAST: paleontological Statistics software package for education and data analysis. Palaeontol. Electron., 4, 1-9.

Hänfling B. and Brandl R., 1998a. Genetic and morphological variation in a common European cyprinid, Leuciscus cephalus within and across central European drainages. J. Fish Biol., 52, 706-715.

Hänfling B. and Brandl R. 1998b. Genetic differences of the bullhead Cottus gobio L. across watersheds in Central Europe: evidence of two taxa. Heredity, 80, 110-117.

Harka Á., 1986. Vizeink küllőfajai. Halászat, 79, 180-182.

Harka Á. and Sallai Z., 2004. Magyarország halfaunája, Nimfea Természetvédelmi Egyesület, Szarvas, 269 p.

Harka Á., Szepesi Zs., Kosco J. and Pavol J., 2004. Adatok a Zagyva vízrendszerének halfaunájához. Halászat, 9, $117-124$.

Jászfalusi L., 1951. Die endemischen Cobitis und Gobio Arten der Tisza, Sowie ihrer Nebenflüsse. Ann. Hist.-Nat. Mus. Nat. Hung., 1, 113-125.

Karakousis Y., Traiantaphyllidis C. and Economidis P.S., 1991. Morphological variability among seven populations of brown trout, Salmo trutta L., in Greece. J. Fish Biol., 38, 807-817.

Koščo J., 1997. Biometric characters of Gobio gobio (L.) from the Tisa Basin. In: Abstracts of the Third Session of the Symposium "Systematics and phylogenesis of the animal world: Systematics of the fishes from the Cyprinidae", Olsztyn-Kortowo, Poland.

Kottelat M. and Freyhof J., 2007. Handbook of European freshwater fishes. Publications Kottelat, Cornol, Switzerland, 646 p.

Kottelat M. and Persat H., 2005. The genus Gobio in France, with redescription of $G$. gobio and description of two new species. Cybium, 29, 211-234.
Mendel J., Lusk S., Vasil'eva E., Vasil'ev V., Lusková V., Ekmekci F., Erk'akan F., Ruchin A., Koščo J., Vetešník L., Halačka K., Šanda R., Pashkov A. and Reshetnikov S., 2008. Molecular phylogeny of the genus Gobio Cuvier, 1816 (Teleostei: Cyprinidae) and its contribution to taxonomy. Mol. Phylogen. Evol., 47, 1061-1075.

Naseka A.M., 1996. Comparative study on the vertebral column in the Gobioninae (Cyprinidae, Pisces) with special reference to its systematics. Publ. Espec. Inst. Esp. Oceanogr., 21, 149-167.

Naseka A.M. and Bogutskaya N.G., 1998. A new gudgeon species Romanogobio pentatrichus (Gobioninae, Cyprinidae) from from the basin of Kuban River. Vopr. Ihtiol., 38, 219-227.

Naseka A.M. and Poznjak V.G., 2000. Northcaucasian longbarbeled gudgeon Romanogobio ciscaucasicus in the basin of the Kuban River (Gobioninae, Cyprinidae). Vopr. Ihtiol., 40, 406-410.

Naseka A.M., Erk'akan F. and Küçük F., 2006. A description of two new species of the genus Gobio from Central Anatolia (Turkey) (Teleostei: Cyprinidae). Zoosyst. Rossica, 15, 185-194.

Neave F.B., Mandrak N.E., Docker M.F. and Noakes D.L., 2006. Effects of preservation on pigmentation and length measurements in larval lampreys. J. Fish Biol., 68, 991-1001.

Nelson J.S., 2006. Fishes of the World, John Wiley \& Sons, Inc., Hoboken, NJ, $601 \mathrm{p}$.

Nowak M., Košo J. and Popek W., 2008a. Review of the current status of systematics of gudgeons (Gobioninae, Cyprinidae) in Europe. AACL Bioflux, 1, 27-38.

Nowak M., Popek W., Drăg-Kozak E., Epler P. 2008 b. Morphology of the common gudgeon, Gobio gobio (L.) sensu lato, from the Vistula River drainage in the context of recent literature data (Teleostei: Cyprinidae). Arch. Pol. Fish., 16, $37-48$.

Nowak M., Petrescu-Mag I.V., Mierzwa D., Popek W., 2009. On some interesting Romanian gudgeons (Cyprinidae: Romanogobio) found in the collection of Museum and Institute of Zoology PAS. AES Bioflux, 1, 81-88.

Nowak M., Mendel J., Szczerbik P., Klaczak A., Mikołajczyk T., Ozga K., Fałowska B. and Popek W., 2011. Contributions to the morphological variation of the common gudgeon, Gobio gobio complex (Teleostei: Cyprinidae), in the upper Vistula drainage (southeast Poland). Arch. Pol. Fish., 19, $37-49$.

Podani J., 2001. SYN-TAX 2000 computer programs for data analysis in ecology and systematics. User's manual. Scientia Publishing, Budapest, $53 \mathrm{p}$.

Sály P., Erős T., Takács P., Kiss I. and Bíró P., 2009. Kisvízfolyások halegyüttestípusai és karakterfajai a Balaton vízgyüjtőjén: élőhelytípus-indikátorok és fajegyüttes-indikátorok. Pisces Hung., 3, 133-146.

Sevcsik A. and Erős T., 2008. A revised catalogue of freshwater fishes of Hungary and the neighbouring countries in the Hungarian Natural History Museum (Pisces). Ann. Hist.-Nat. Mus. Nat. Hung., 100, 331-383.

Shields A.S. and Carlson S.R., 1996. Effects of formalin and alcohol preservation on lengths and weights of juvenile sockeye salmon. Alaska Fish. Res. Bull., 3, 81-93.

Taberlet P., Fumagalli L., Wust-Saucy A. and Conosson J., 1998. Comparative phylogeography and postglacial colonization routes in Europe. Mol. Ecol., 7, 453-464. 
Takács P., 2007. Dombvidéki és síkvidéki kisvízfolyások halállományainak összehasonlító vizsgálata. Acta Agraria Debr. Suppl. Pisces Hung. I., 25, 54-59.

Takács P., Csoma E., Erős T. \& Nagy S.A., 2008. Distribution patterns and genetic variability of three stream-dwelling fish species. Acta Zool. Sci. Hung., 54, 209-303.

Turan C., Yalçın Ş., Turan F., Okur E., and Akyurt İ., 2005. Morphometric comparisons of African catfish, Clarias gariepinus, populations in Turkey. Folia Zool., 54, 165-172.

Vasil'eva E.D., Vasil'ev V.P. and Kuga T.I., 2004. On the taxonomy of gudgeons of the genus Gobio (Gobioninae, Cyprinidae) of Europe: a new gudgeon species Gobio kubanicus sp. nova from the Kuban' River drainage. Vopr. Ichtiol., 44, 766-782.

Vasil'eva E.D., Vasil'ev V.P. and Boltachev A.R., 2005. Taxonomic relationships of gudgeons (Gobio, Gobioninae, Cyprinidae) of Crimea. J. Ichthyol., 4, 730-743.

Vladykov V., 1925. Über einige neue Fische aus der Tschechoslowakei (Karpathorußland). Zool. Anz., 72, 248-252.

Yang J., He S., Freyhof J., Witte K. and Liu H., 2006. The phylogenetic relationships of the Gobioninae (Teleostei: Cyprinidae) inferred from mitochondrial cytochrome $b$ gene sequences. Hydrobiologia, 553, 255-266. 